\title{
Performance of Tomato Hybrids for Growth, Yield and Quality under Western Track of Vindhyan Plateau of Madhya Pradesh, India
}

\author{
Bhagwan Bamaniya $^{1}$, S. A. Ali $^{2}$, S. R. Ramgiri ${ }^{2}$, Arpita Shrivastava ${ }^{*}$ and R. P. Bain ${ }^{1}$ \\ ${ }^{1}$ Department of agronomy, Krishi Vigyan Kendra, Katni \\ ${ }^{2}$ RAK College of Agriculture, Sehore \\ *Corresponding author
}

\section{A B S T R A C T}

\section{Keywords}

Hybrid, Growth and yield parameters, Tomato

Article Info

Accepted:

17 November 2019

Available Online:

10 December 2019
A field experiment was conducted during late kharif, 2013 at Horticulture Research Farm, R.A.K. College of Agriculture, Sehore (M.P) to study growth, yield parameters on twelve hybrids of tomato. Design of experiment was RBD with three replications. Observation on traits related to plant morphology, maturity and yield component were recorded to develop, evaluate, identify and recommend high yielding hybrids of tomato). Fruit yield per ha of 12 hybrids ranged from 356.4 to $656.6 \mathrm{q} / \mathrm{ha}$ with the average of $454.18 \mathrm{q} / \mathrm{ha}$. The hybrid produced highest yield NTH-2530 (656.60 q/ha) followed by Bhumika $(578.13 \mathrm{q} / \mathrm{ha})$ and Laxmi NP-5005(508.43 q/ha) while hybrid produced lowest yield VS-440 (356.40 q/ha) followed by H-86 (366.77 q/ha) and Shantuna-2131 (372.9 q/ha). In conclusion, despite environmental and other yield constraints encountered by these hybrids during the growth period, NTH-2530 and Bhumika gave the highest growth, marketable and good quality fruit yield performance. Therefore, these hybrids can be recommended as the best tomato hybrids in western track of Vindhyan plateau of Madhya Pradesh.

\section{Introduction}

Tomato is one of the most popular and widely grown vegetables and recognized as important commercial and dietary vegetable crops (Singh et al., 2014). Tomato has become an important vegetable of the world in view of the increasing demand for fresh consumption as well as processing industry. Fresh fruits of tomato are in great demand round the year and throughout the country (Kumar et al., 2017). It is an important condiment and a very cheap source of vitamins. It also contains a large quantity of water (\%), calcium (\%) and Niacin all of which are of great importance in the metabolic activities of man (Olaniyi et al., 2010). Tomato is a good source of vitamins $A$, $\mathrm{C}$ and $\mathrm{E}$ and minerals that are very good for body and protect the body against diseases (Taylor, 1987). 
Tomato ranks second following potato in terms of area cultivated, but first as a processing crop (Alawathugoda and Dahanayake, 2014; Enujeke, 2013). Productivity of tomato is affected by the several biotic and abiotic factors. For the stable production, testing of new varieties/ hybrids must be adopted. Crop growth and yield are usually affected by varietal differences (Naik et al., 2018).

Development of hybrid tomato varieties having desirable characters has proven to be an effective strategy to increase tomato production. The yield of hybrid tomato is 20 to $25 \%$ more as compared to open pollinated (Islam et al., 2012 and Devkota et al., 2018). The growth characters of crops such as plant height, leaf area, number of leaves or branches and fruit yield were influenced by genetic factors of different varieties ((Majambu et al., 1996 and Sajjan et al., 2002). Thus, the biometrical information gathered on genetic architecture of attributes related to fruit yield and productivity would be great utility in planning of an efficient breeding programme for the improvement of tomato crop in order to develop promising genotypes/ cultivars (Naik et al., 2018).

Keeping this view, the present study was focused to evaluate growth, fruit yield and quality of tomato hybrids under western track of Vindhyan plateau of Madhya Pradesh.

\section{Materials and Methods}

The present investigation conduct at the Horticulture Research Farm, R.A.K. College of Agriculture, Sehore, (M.P) during late kharif season (2011). The experimental material comprised of twelve hybrids, which were collected from the market. The hybrids were transplanted after 30 DAS in randomized block design with three replications. Plants of each genotype were planted at a spacing of 60x50 cm. Standard cultural practices (Operations \& Protection measures) were adopted to ensure a healthy crop growth.

The hybrids were evaluated for some important character viz., plant height $(\mathrm{cm})$, number of branch per plant at final picking, days to flower initiation, days to fruit initiation, days to first picking, number of flowers per cluster, number of flower clusters per plant, number of fruit per cluster, number of fruit per plant after final picking, number of fruits per picking, number of locules per fruit, fruit girth $(\mathrm{cm})$, fruit length $(\mathrm{cm})$, weight of fruit $(\mathrm{g})$, fruit yield per plant $(\mathrm{kg})$, fruit yield per plot $(\mathrm{kg})$, fruit yield per ha (q/ha).

The quality characters viz., type of plant, colour of fruit, fruit shape, T.S.S. (Brix) and keeping quality also recorded. The data was analysed as per the method given by (Panse and Sukhatme, 1967). Least significant difference at $5 \%$ level was used for finding the significant differences among the treatment means.

\section{Results and Discussion}

Data recorded on growth parameter observations and response of twelve hybrids is presented in Table 1 and 2.

\section{Plant height (at 30 DAT and at final picking)}

The plant height increased with the plant aged. The plant height at 30 DAT varied from 25.00 to $50.80 \mathrm{~cm}$ with mean performance of 41.56 $\mathrm{cm}$. US-618 had lowest plant height $(25.00$ $\mathrm{cm})$, while hybrid Anirudh recorded maximum plant height $(50.80 \mathrm{~cm})$.

At final picking, it was observed that plant height mean was $186.44 \mathrm{~cm}$ and ranged 153.67 to $245.33 \mathrm{~cm}$. US-618 recorded the lowest $(153.67 \mathrm{~cm})$ plant height, while VS- 
440 showed the maximum plant height $(245.33 \mathrm{~cm})$.

Number of primary branches per plant at final picking

Among the 12 hybrids, maximum number of branches per plant was recorded with hybrid Pahuja-508 (18.67) and minimum with Laxmi NP-5005(10.50) with an average of 14.75 .

\section{Phonological characters}

Days to flower initiation, ranged between 33.33 days (Vigro) to 41.33 days (Laxmi NP5005 ) with an average of 37.22 days. The maximum days to flower initiation were observed in Pusa rubi, (64.00) while Anirudh had minimum (52.00) days to fruit initiation with a mean value of 56.52 days.

Among the 12 hybrids days required to first picking ranged from 84.81 days (Pahuja-508) to 95.79 days (Bhumika) with the average of 91.27 days.

\section{Number of flower clusters per plant}

The number of flower clusters per plant has been ranged from 53.91 (Vigro) to 27.45 (Laxmi NP-5005).

\section{Number of flowers per cluster}

The maximum number of flowers per cluster was observed in hybrid Bhumika (7.08) followed by Shantuna (6.75) while lowest number of flower per cluster counted in Laxmi NP-5005 (3.67).

\section{Number of fruits per cluster}

Result showed that hybrid Anirudh (5.64) was significantly superior over rest of hybrids and it was followed by Bhumika (5.28) while minimum number of fruits per cluster recorded in the hybrid VS-440 (3.69).

\section{Number of fruits per picking}

The maximum number of fruits per picking at 90 DAT was observed in hybrid NTH2530(12.67) followed by Bhumika (9.67) and H-86 (9.67) while lowest number of fruits per picking was recorded in the hybrid Anirudh (7.67). The highest number of fruits per picking at 115 DAT was found in hybrid NTH-2530 (17.00) followed by Pahuja-508 (12.00) and Bhumika (12.00) while lowest number of fruits per picking found in the hybrid Laxmi NP-5005 (10.00).

The maximum number of fruits per picking at 140 DAT was expressed by NTH-2530(14.00) followed by US-618 (11.33) and H-86 (10.67) while lowest in the hybrid VS-440 (9.67). The maximum number of fruit per plant at final picking was noted in the hybrid NTH-2530 (43.67) followed by Bhumika (31.67) whereas the minimum number of fruit was found in hybrid Anirudh (28.33).

\section{Fruit characters}

The number of locules per fruit ranged from 2 (Shantuna-2131, Anirudh, VS-440, Pahuja508 and NTH-1) to 4 (Laxmi NP-5005 and $\mathrm{NBH}-1)$. The length of fruit $(\mathrm{cm})$ varied from 5.99 (Laxmi NP-5005) to $8.02(\mathrm{NTH}-1) \mathrm{cm}$ with an average of $6.74 \mathrm{~cm}$. The maximum girth was observed in hybrid Laxmi NP-5005 (7.26) whereas; minimum width in hybrid Pusa rubi $(5.10 \mathrm{~cm})$. The weight of fruits ranged from $35.51 \mathrm{~g}(\mathrm{H}-86)$ to $47.67 \mathrm{~g}$ (NTH2530) with an average of $41.92 \mathrm{gm}$.

\section{Fruit yield}

The fruit yield per plant varied from $1.069 \mathrm{~kg}$ to $1.970 \mathrm{~kg}$ with the average of $1.36 \mathrm{~kg}$. The highest yielding hybrid was NTH-2530 (1.970 $\mathrm{kg})$ followed by Bhumika $(1.73 \mathrm{~kg})$ and Laxmi NP-5005 $(1.53 \mathrm{~kg})$, while VS-440 gave the lowest yield per plant (1.069) Followed by H$86(1.100 \mathrm{~kg})$. 
Table.1 Plant height, phonological characters, number of flowers and number of fruits characters of tomato hybrids

\begin{tabular}{|c|c|c|c|c|c|c|c|c|c|c|c|}
\hline $\begin{array}{c}\text { S. } \\
\text { No. }\end{array}$ & Hybrids & $\begin{array}{l}\text { Plant } \\
\text { height } \\
\text { at } 30 \\
\text { days } \\
\text { (cm) }\end{array}$ & $\begin{array}{c}\text { Plant } \\
\text { height } \\
\text { at final } \\
\text { picking } \\
\text { (cm) }\end{array}$ & $\begin{array}{l}\text { No. of } \\
\text { branch } \\
\text { at final } \\
\text { picking }\end{array}$ & $\begin{array}{l}\text { Days to } \\
\text { flower } \\
\text { initiation }\end{array}$ & $\begin{array}{c}\text { Days to } \\
\text { fruit } \\
\text { initiation }\end{array}$ & $\begin{array}{c}\text { Day to } \\
\text { first } \\
\text { picking }\end{array}$ & $\begin{array}{l}\text { No. of } \\
\text { flower } \\
\text { clusters } \\
\text { /plant }\end{array}$ & $\begin{array}{l}\text { No. of } \\
\text { flowers/ } \\
\text { cluster }\end{array}$ & $\begin{array}{l}\text { No. of } \\
\text { fruits/ } \\
\text { cluster }\end{array}$ & $\begin{array}{c}\text { No. of } \\
\text { fruits/ } \\
\text { plant } \\
\text { after final } \\
\text { picking }\end{array}$ \\
\hline 1. & US-618 & 25.00 & 153.67 & 13.99 & 39.00 & 55.67 & 91.88 & 42.67 & 5.17 & 4.40 & 31.33 \\
\hline 2. & SHANTUNA-2131 & 41.40 & 194.67 & 16.67 & 39.33 & 54.33 & 94.07 & 53.43 & 6.75 & 4.56 & 29.33 \\
\hline 3. & VIGRO & 37.60 & 153.67 & 12.38 & 33.33 & 53.33 & 93.23 & 53.91 & 5.08 & 4.45 & 29.67 \\
\hline 4. & ANIRUDH & 50.80 & 224.33 & 14.81 & 39.00 & 52.00 & 92.25 & 33.21 & 6.70 & 5.64 & 28.33 \\
\hline 5. & BHUMIKA & 42.74 & 212.33 & 15.13 & 35.33 & 52.33 & 95.79 & 35.51 & 7.08 & 5.28 & 31.67 \\
\hline 6. & VS-440 & 39.32 & 245.33 & 16.30 & 38.33 & 55.00 & 92.23 & 35.38 & 4.63 & 3.69 & 30.00 \\
\hline 7. & H-86 & 46.83 & 177.67 & 11.67 & 38.00 & 58.00 & 94.20 & 37.45 & 5.08 & 4.08 & 31.00 \\
\hline 8. & LAXMI NP-5005 & 50.33 & 173.33 & 10.50 & 41.33 & 54.33 & 85.42 & 27.45 & 3.67 & 4.72 & 28.67 \\
\hline 9. & NBH-1 & 39.87 & 162.00 & 15.00 & 36.33 & 61.67 & 93.37 & 40.46 & 5.64 & 4.32 & 29.00 \\
\hline 10. & PUSA RUBI & 46.87 & 164.33 & 14.24 & 34.00 & 64.00 & 88.92 & 42.34 & 5.45 & 4.45 & 29.33 \\
\hline 11. & PAHUJA- 508 & 36.29 & 192.67 & 18.67 & 38.00 & 63.00 & 84.81 & 41.19 & 5.61 & 4.46 & 31.67 \\
\hline 12. & NTH-2530 & 41.68 & 183.33 & 17.67 & 34.67 & 54.67 & 89.37 & 49.21 & 5.62 & 4.45 & 43.67 \\
\hline & SEm \pm & 2.33 & 2.02 & 0.41 & 0.60 & 0.60 & 0.66 & 0.71 & 0.06 & 0.03 & 0.76 \\
\hline & CD at $5 \%$ & 4.83 & 4.20 & 0.86 & 1.24 & 1.26 & 1.38 & 1.47 & 0.12 & 0.06 & 1.59 \\
\hline
\end{tabular}

Number in bold represent maximum and minimum value 
Table.2 Fruit picking, fruits characters, fruit yield and quality characters of tomato hybrids

\begin{tabular}{|c|c|c|c|c|c|c|c|c|c|c|c|c|c|}
\hline $\begin{array}{c}\text { S. } \\
\text { No. }\end{array}$ & Hybrids & $\begin{array}{l}\text { Number } \\
\text { of fruits } \\
\text { per } \\
\text { picking } \\
\text { (90 } \\
\text { DAT) }\end{array}$ & $\begin{array}{c}\text { Number } \\
\text { of fruits } \\
\text { per } \\
\text { picking } \\
\text { (115 } \\
\text { DAT) }\end{array}$ & $\begin{array}{c}\text { Number } \\
\text { of fruits } \\
\text { per } \\
\text { picking } \\
\text { (140 } \\
\text { DAT) }\end{array}$ & $\begin{array}{c}\text { Number } \\
\text { of } \\
\text { locules } \\
\text { per } \\
\text { fruit }\end{array}$ & $\begin{array}{c}\text { Length } \\
\text { of fruit } \\
\text { (cm) }\end{array}$ & $\begin{array}{l}\text { Girth } \\
\text { of } \\
\text { fruit } \\
(\mathrm{cm})\end{array}$ & $\begin{array}{c}\text { Weight/ } \\
\text { fruit } \\
\text { (gm.) }\end{array}$ & $\begin{array}{c}\text { Fruit } \\
\text { yield/ } \\
\text { plant } \\
\text { (kg.) }\end{array}$ & $\begin{array}{l}\text { Fruit } \\
\text { yield/ } \\
\text { plot } \\
(\text { Kg.) }\end{array}$ & $\begin{array}{c}\text { Fruit } \\
\text { yield/ha } \\
\text { (q/ha) }\end{array}$ & $\begin{array}{c}\text { Total } \\
\text { soluble } \\
\text { solids } \\
\text { (TSS) } \\
{ }^{\text {oBrix }}\end{array}$ & $\begin{array}{c}\text { Keeping } \\
\text { quality } \\
\text { in days }\end{array}$ \\
\hline 1. & US-618 & 8.33 & 11.67 & 11.33 & 3.0 & 6.47 & 6.78 & 42.64 & 1.372 & 34.31 & 457.5 & 4.3 & 8.7 \\
\hline 2. & SHANTUNA-2131 & 8.33 & 11.00 & 10.00 & 2.0 & 6.55 & 5.57 & 38.22 & 1.119 & 27.97 & 372.9 & 4.7 & 8.7 \\
\hline 3. & VIGRO & 8.33 & 11.00 & 10.33 & 3.0 & 6.83 & 5.65 & 45.63 & 1.378 & 34.44 & 459.2 & 3.3 & 11.4 \\
\hline 4. & ANIRUDH & 7.67 & 10.67 & 10.00 & 2.0 & 6.79 & 5.90 & 45.01 & 1.272 & 31.81 & 424.2 & 3.2 & 6.6 \\
\hline 5. & BHUMIKA & 9.67 & 12.00 & 10.00 & 3.0 & 7.10 & 6.34 & 43.15 & 1.734 & 43.36 & 578.1 & 3.8 & 6.6 \\
\hline 6. & VS-440 & 9.33 & 11.00 & 9.67 & 2.0 & 6.73 & 5.84 & 35.65 & 1.069 & 26.73 & 356.4 & 4.4 & 12.5 \\
\hline 7. & H-86 & 9.67 & 10.67 & 10.67 & 2.0 & 6.24 & 6.54 & 35.51 & 1.100 & 27.51 & 366.8 & 4.4 & 7.9 \\
\hline 8. & LAXMI NP-5005 & 8.33 & 10.00 & 10.33 & 4.0 & 5.99 & 7.26 & 43.87 & 1.525 & 38.13 & 508.4 & 2.2 & 14.0 \\
\hline 9. & NBH-1 & 8.67 & 10.33 & 10.00 & 4.0 & 6.80 & 6.71 & 43.24 & 1.313 & 32.83 & 437.7 & 5.1 & 10.5 \\
\hline 10. & PUSA RUBI & 8.33 & 10.67 & 10.33 & 2.0 & 6.37 & 5.10 & 42.47 & 1.230 & 30.75 & 410.1 & 4.4 & 5.9 \\
\hline 11. & PAHUJA- 508 & 9.00 & 12.00 & 10.67 & 2.0 & 7.06 & 5.62 & 40.06 & 1.267 & 31.67 & 422.3 & 2.7 & 14.4 \\
\hline 12. & NTH-2530 & 12.67 & 17.00 & 14.00 & 2.0 & 8.02 & 5.86 & 47.67 & 1.970 & 49.24 & 656.6 & 3.9 & 12.8 \\
\hline & SEm \pm & 0.40 & 0.43 & 0.41 & - & 0.14 & 0.04 & 0.52 & 0.03 & 0.85 & 11.43 & 0.035 & 0.064 \\
\hline & CD at $5 \%$ & 0.84 & 0.89 & 0.85 & - & 0.30 & 0.09 & 1.08 & 0.20 & 1.77 & 23.70 & 0.076 & 0.134 \\
\hline
\end{tabular}

Number in bold represent maximum and minimum value 
The lowest fruit yield per plot was observed in VS-440 (26.73) and highest (49.24 kg) was under NTH-2530 hybrid followed by Bhumika $(43.36 \mathrm{~kg})$ and Laxmi NP-5005 (38.13 kg).

Fruit yield per ha of 12 hybrids ranged from 356.4 to $656.6 \mathrm{q} / \mathrm{ha}$ with the average of 454.18 $\mathrm{q} /$ ha. The hybrid produced highest yield NTH2530 (656.60 q/ha) followed by Bhumika (578.13 q/ha) and Laxmi NP-5005(508.43 $\mathrm{q} / \mathrm{ha}$ ) while hybrid produced lowest yield VS$440(356.40 \mathrm{q} / \mathrm{ha})$ followed by H-86 (366.77 q/ha) and Shantuna-2131 (372.9 q/ha).

\section{Total soluble solids (TSS) ${ }^{\circ}$ Brix}

The total soluble solids (TSS) of 12 hybrids ranged from 2.20 to $5.10{ }^{\circ} \mathrm{Brix}$ with the average of 3.65. Hybrid NBH-1 recorded highest TSS (5.10 ${ }^{\circ}$ Brix), whereas, hybrid Laxmi NP-5005 recorded lowest value of TSS (2.20 ${ }^{\circ}$ Brix).

\section{Keeping quality in days}

Among the 12 hybrids keeping quality was tested and ranged from 5.90 to 14.40 days with the average of 10.15 days Pusa rubi showed minimum shelf life (5.90 days), hybrids Pahuja-508 showed maximum shelf life (14.40 days).

The varietals differences in growth and yield might be attributed to the differences in ecological distribution of the tomato varieties (Olaniyi, 2007) and genetic constitution of crop varieties (Majanbu et al., 1996; Ibrahim et al.,.2000 and Sajjan et al., 2002). The maximum plant height was recorded in VS440, number of branches/plant in Pahuja-508, weight of fruit NTH-2530, total soluble solids NBH-1, keeping quality Pahuja-508, fruit length in NTH-2530 and Fruit girth in Laxmi NP-5005. The hybrid produced highest yield NTH-2530 followed by Bhumika and Laxmi NP-5005, while hybrid produced lowest yield
VS-440 followed by H-86 and Shantuna-2131. The variation in yield may also be due to genetic differences among the varieties since they were grown under the same environmental conditions (Olaniyi and Fagbayide, 1999; Olaniyi et al., 2010). In conclusion, despite environmental and other yield constraints encountered by these hybrids during the growth period NTH-2530 and Bhumika gave the highest growth, marketable and good quality fruit yield performance. Therefore, these hybrids can be recommended as the best tomato hybrids in western track of Vindhyan plateau of Madhya Pradesh.

\section{Acknowledgement}

The authors would like to extend my deepest sense of Horticulture Research Farm, R.A.K. College of Agriculture, Sehore, (M.P) for providing the research grant for conducting the experiment.

\section{References}

Alawathugoda, C.J. and Dahanayake, N. 2014. Effects of micorrhizae as a substitute for inorganic fertilizer on growth and yield of tomato (Lycopersicon esculentum L.) and Soybean (Glycin max L.) and soil microbial activity. Trop. Agric. Res. Exten. 16 (4): 107112.

Devkota S., S.L. Shrestha, D.D. Dhakal, S.M. Shakya and Pandey A. 2018. Evaluation of tomato hybrids for yield attributes under khumaltar condition. J. Inst. Agric. Anim. Sci. 35: 191-196.

Enujeke, E.C. 2013. Effects of variety and spacing on growth characters of hybrid maize. Asian J. Agric. Ru. Dev. 3(5): 296-310.

Ibrahim, A., A. Amans and Abubakar, I.U. 2000. Growth indices and yield of tomato (Lycopersicon esculentum karest) varieties as influenced by crop 
spacing at samara. Proc. 18th HORTSON Conf. Proc. 1: 40-47.

Islam M. R, S. Ahmad and Rahman M.M. 2012. Heterosis and qualitative attributes in winter tomato (Solanum lycopersicum L.) hybrids. Bangladesh J. Agric. Res. 37(1): 39-48.

Kumar S., M.L. Meena, D.C. Meena, J.K. Meena, S. Kishor and Kishor S. 2017 Performance of tomato germplasms for growth, yield and quality under Lucknow conditions. Journal of Pharmacognosy and Phytochemistry. 6(4): 1560-1562.

Majanbu, I.S., V.B. Ogunlella and Ahmed M.K. 1996. Response of two okra (Abelmoschus esculentus) varieties to fertilizer growth and nutrient concentration as influenced by nitrogen and phosphorus applications. Fer. Res. 8(3): 297-306.

Naik, M.R., C.H. Ruth and Chinnabbai, C.H. 2018. Growth, flowering and yield response of tomato varieties under polyhouse conditions. Int. J. Pure App. Biosci. 6(1): 1303-1307.

Olaniyi J.O. 2007. Evaluation of yield and quality performance of grain amaranth varieties in the South western Nigeria Res. J. Agron., 1(2): 42-45.

Olaniyi J.O. and Fagbayide J.A. 1999.
Performance of eight $F_{1}$ hybrid cabbage (Brassica olerácea 1.) varieties in the Southern Guinea Savanna zone of Nigeria. J. Agric. Biotechnol. Environ. 1: 4-10.

Olaniyi J.O., W.B. Akanbi, T.A. Adejumo and Akande O.G. 2010. Growth, fruit yield and nutritional quality of tomato varieties. African Journal of Food Science. 4(6): 398 - 402.

Panse V.G. and Sukhatme P.V. 1967. Statistical methods. Oxford and IBM Pub. Co. New Delhi INDIA.

Sajjan, A.S., M. Shekhargounda and Badanur, K. 2002. Influence of date of sowing, spacing and levels of nitrogen on yield attributes and seed yield of okra. J. Agric. Sci. 15(2): 267-274.

Singh, T., N. Singh, A. Bauguna, M. Nautiyal and Sharma, V.K. 2014. Performance of tomato (Solanum lycopersicum L.) Hybrids for growth, yield and quality inside polyhouse under mid hill condition for Uttarakhanda. American journal of drug discovery and development, 4(3), 202-209.

Taylor J.H. 1987. Text of lectures delivered at the national workshop on fruit and vegetable seedlings. Production held at NIHORT 9-13

\section{How to cite this article:}

Bhagwan Bamaniya, S. A. Ali, S. R. Ramgiri, Arpita Shrivastava and Bain, R. P. 2019. Performance of Tomato Hybrids for Growth, Yield and Quality under Western Track of Vindhyan Plateau of Madhya Pradesh, India. Int.J.Curr.Microbiol.App.Sci. 8(12): 2226-2232. doi: https://doi.org/10.20546/ijcmas.2019.812.265 